\title{
The Biased G-Protein-Coupled Receptor Agonism Bridges the Gap between the Insulin Receptor and the Metabolic Syndrome
}

\author{
Iryna Liauchonak ${ }^{1,+}$, Fady Dawoud ${ }^{1,+}$, Yatin Riat ${ }^{1,+}$, Bessi Qorri ${ }^{2,+}{ }^{(0)}$, Manpreet Sambi ${ }^{2,+}$, \\ Justin Jain ${ }^{1}$, Regina-Veronicka Kalaydina ${ }^{2}$, Nicole Mendonza ${ }^{2}$, Komal Bajwa ${ }^{1}$ and \\ Myron R. Szewczuk 2,* (D) \\ 1 Postgraduate Medical Education, Graduate Diploma and Professional Master in Medical Sciences, \\ School of Medicine, Queen's University, Kingston, ON K7L 3L4, Canada; iryna.liauchonak@gmail.com (I.L.); \\ fady.dawoud@hotmail.com (F.D.); riatyatin@gmail.com (Y.R.); justin.jain@queensu.ca (J.J.); \\ bajwa.komal@queensu.ca (K.B.) \\ 2 Department of Biomedical and Molecular Science, Queen's University, Kingston, ON K7L 3N6, Canada; \\ bessi.qorri@queensu.ca (B.Q.); m.sambi@queensu.ca (M.S.); nicka.kalaydina@queensu.ca (R.-V.K.); \\ nicole.mendonza@queensu.ca (N.M.) \\ * Correspondence: szewczuk@queensu.ca; Tel.: +1-613-533-2457 \\ + These authors contributed equally to this work.
}

Received: 1 February 2018; Accepted: 15 February 2018; Published: 17 February 2018

\begin{abstract}
Insulin signaling, as mediated through the insulin receptor (IR), plays a critical role in metabolism. Aberrations in this signaling cascade lead to several pathologies, the majority of which are classified under the umbrella term "metabolic syndrome". Although many of these pathologies are associated with insulin resistance, the exact mechanisms are not well understood. One area of current interest is the possibility of G-protein-coupled receptors (GPCRs) influencing or regulating IR signaling. This concept is particularly significant, because GPCRs have been shown to participate in cross-talk with the IR. More importantly, GPCR signaling has also been shown to preferentially regulate specific downstream signaling targets through GPCR agonist bias. A novel study recently demonstrated that this GPCR-biased agonism influences the activity of the IR without the presence of insulin. Although GPCR-IR cross-talk has previously been established, the notion that GPCRs can regulate the activation of the IR is particularly significant in relation to metabolic syndrome and other pathologies that develop as a result of alterations in IR signaling. As such, we aim to provide an overview of the physiological and pathophysiological roles of the IR within metabolic syndrome and its related pathologies, including cardiovascular health, gut microflora composition, gastrointestinal tract functioning, polycystic ovarian syndrome, pancreatic cancer, and neurodegenerative disorders. Furthermore, we propose that the GPCR-biased agonism may perhaps mediate some of the downstream signaling effects that further exacerbate these diseases for which the mechanisms are currently not well understood.
\end{abstract}

Keywords: insulin receptor signaling; G protein-coupled receptors; metabolic syndrome; GPCR biased agonism; angiotensin; bradykinin; gut microbiota; ghrelin; polycystic ovarian syndrome; pancreatic cancer; Alzheimer's

\section{Introduction}

Activation of the insulin receptor (IR) and its downstream signaling is critical to maintaining metabolic homeostasis and represents a significant area of interest in biology and medicine [1]. This receptor is of particular relevance due to its crucial role in metabolism and the development of 
metabolic syndrome. Metabolic syndrome (MetSyn) is defined as the combination of conditions that increase the risk of cardiovascular disease and type two diabetes mellitus (T2DM) [2]. However, the specific underlying biochemical and cellular properties of IR signaling that may contribute to the development of this syndrome have not yet been identified.

IR activation follows the conventional ligand-receptor interaction and involves the binding of insulin to the IR, resulting in broad signaling that occurs through three main biochemical steps. First, tyrosine phosphorylation of the IR and its substrates occurs and is followed by the activation of phosphoinositide 3-kinase (PI3K) (a lipid kinase), and culminates with the activation of serine/threonine kinases, the most important being protein kinase B (AKT) [3]. Although it is still debated, it has been well-documented that activation of the IR requires ligand-induced receptor dimerization, which is a characteristic of the entire family of receptor tyrosine kinases (RTKs) and also a ubiquitous property of G-protein-coupled receptors (GPCRs) [4]. Although IR and GPCR signaling initiate separate signaling cascades exclusive to these receptors, a growing body of evidence has identified a previously unknown link between the two signaling platforms. Evidence indicating a "missing link" suggests that the IR initiates metabolic events by signaling through a heterotrimeric G protein $[1,5]$.

Although GPCRs are some of the most comprehensively studied and well-characterized proteins, recent studies have revealed an additional facet of these proteins, namely the phenomenon of biased agonism or functional selectivity, which is characterized as preferential activation of certain pathways by a ligand [6,7]. The novel concept of the GPCR-biased agonism has been further developed by the recent discovery of a bias that results in IR activation and signaling in the absence of insulin [8]. This unique finding may represent the missing link between GPCR and IR signaling that could contribute to the development of the complex conditions of metabolic syndrome. Here, we aim to provide an overview of GPCR-biased agonism and its proposed mechanism of action in activating the insulin receptor in the absence of insulin. We also aim to highlight specific ligands that promote this bias and the critical roles they play in metabolic syndrome. Finally, we aim to expand on several pathologies that are either classified as or are exacerbated by metabolic syndrome and identify additional disease states on which GPCR-biased agonism for the insulin receptor may play a role.

\section{Mechanism of Action}

\subsection{An Overview of Normal Insulin Receptor Signaling}

The insulin receptor is synthesized as a preproreceptor. Following cleavage of a signal peptide, the proreceptor undergoes glycosylation, folding, and dimerization $[9,10]$. In a similar fashion to other RTKs, the final IR consists of a heterotetrameric complex comprised of two extracellular $\alpha$ subunits (IR $\alpha$ ) and two membrane-spanning tyrosine kinase-containing $\beta$ subunits (IR $\beta$ ) linked by disulfide bonds [10]. Following insulin binding to the IR $\alpha$, a conformational change occurs in the receptor that transmits a signal across the plasma membrane and activates the intrinsic tyrosine kinase domain within the IR $\beta$. This change results in a series of intermolecular auto-phosphorylation reactions on the tyrosine residues, at which point the IR recruits various substrates and proteins to exert its downstream effects [9].

The highly glycosylated state of the IR [10] is particularly relevant to its possible relationship with the GPCR-biased agonism. Specifically, Alghamdi and colleagues have shown that the cleavage of $\alpha-2,3$ sialic acid residues on the insulin receptor, as well as other RTKs, plays a critical role in receptor activation [11]. As shown in Figure 1, the IR $\alpha$ subunits potentiate GPCR-signaling and matrix metalloproteinase-9 (MMP9) activation. MMP9 removes elastin-binding protein (EBP) that exists as part of a multi-enzymatic complex that contains neuraminidase-1 (Neu-1). Activated Neu-1 hydrolyzes $\alpha-2,3$ sialic acid residues on the IR $\beta$ subunits to remove steric hindrance and allow for receptor dimerization. Once the phospho-IR $\beta$ subunits phosphorylate insulin receptor substrate 1 (IRS1), an intracellular insulin signaling cascade is initiated via several pathways, including the 
Ras-mitogen-activated protein kinase (MAPK) and PI3K-AKT pathways [11]. Therefore, this body of evidence suggests that GPCR-biased agonism could mediate the development of insulin resistance.

(A)

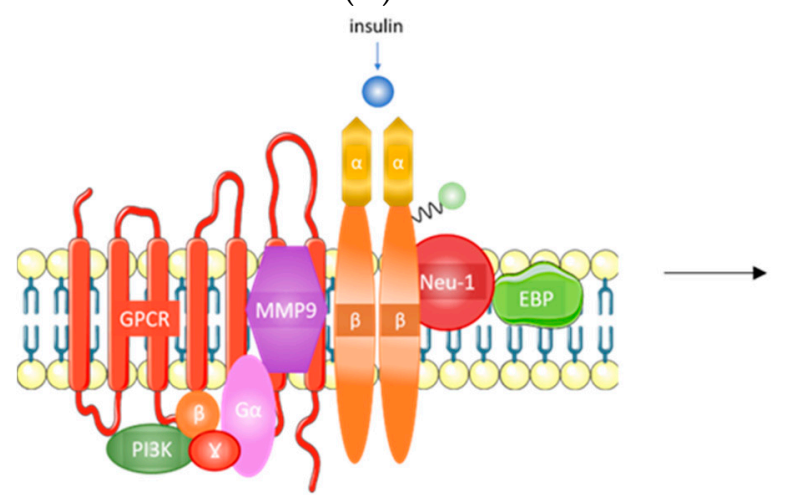

(B)



Figure 1. Overview of insulin signaling. (A) Insulin binding to the IR $\alpha$ and (B) potentiates GPCR signaling that activates MMP9 (1). Active MMP9 relieves restrictive EBP that activates Neu-1 (2). Activated Neu- 1 cleaves $\alpha-2,3$ sialic acid residues on IR $\beta$ to remove steric hindrance and allow for receptor dimerization (3). IR $\alpha, \alpha$ subunit of the insulin receptor; GPCR, G-protein coupled receptor; MMP9, matrix metalloproteinase 9; EBP, elastin binding protein; Neu-1, neuraminidase-1; IR $\beta$, $\beta$ subunit of the insulin receptor; PI3K, phosphoinositide 3-kinase. Taken in part from Alghamdi et al. [11] () 2014 The Authors. http:/ / dx.doi.org/10.1016/j.cellsig.2014.02.015. Published by Elsevier Inc. This is an open access article under the CC BY-NC-ND license (http:/ / creativecommons. org/licenses/by-nc-nd/3.0/).

\subsection{Proposed G Protein-Coupled Receptor (GPCR) Biased Agonism}

As discussed, GPCRs are implicated in IR signaling [11]. Haxho et al. recently discovered an innovative approach for targeting insulin receptor signaling by exploiting GPCR-biased agonism with the neuromedin B receptor (NMBR) [8]. The finding that GPCR activation in the absence of insulin correlated with downstream IR signaling constituted the basis for this approach [12]. Additional evidence substantiating the concept of GPCR-biased agonism with NMBR for IR activation includes the discovery that NMBR exists in a complex with IR $\beta$ subunits on the cell membrane [11]. Haxho et al. found that GPCR agonists bombesin, bradykinin (BK), angiotensin I, and angiotensin II each significantly and dose-dependently induced Neu-1 sialidase activity and IR activation in human IR-expressing rat hepatoma cell lines (HTC-IR) in the absence of insulin [8]. Protein expression analyses demonstrated that the four GPCR agonists induced phosphorylation of IRS1. Additionally, it was found that angiotensin II type I receptor existed in a multimeric receptor complex with Neu-1, suggesting a molecular link for GPCR agonist-induced IR transactivation signaling mediated by Neu-1 and the modification of IR glycosylation [8] (Figure 2).

This novel GPCR-biased agonism in relation to activating the IR, irrespective of the presence of its ligand, has significant implications in MetSyn and may perhaps address the unknown aspects of disease progression, particularly as it relates to cardiovascular disease, irritable bowel disease, obesity, polycystic ovarian syndrome (PCOS), pancreatic cancer, and neuropathologies. 


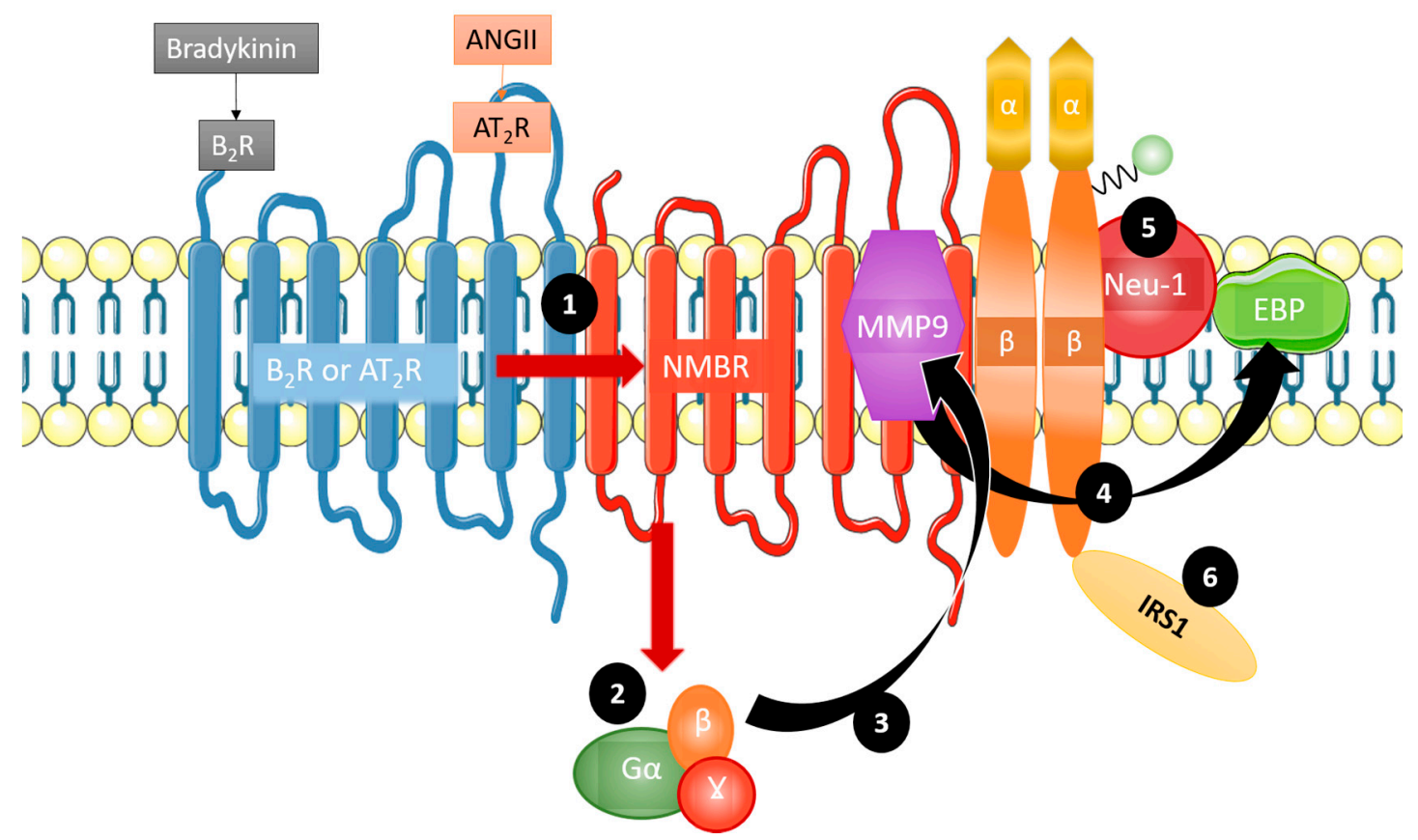

Figure 2. Mechanism of GPCR agonism bias towards insulin receptor activation. Bradykinin and angiotensin II are complexed with the neuromedin B receptor (NMBR), IR $\beta$, and Neu-1. Bradykinin and angiotensin II preferentially lead to insulin receptor signaling by first forming a complex with NMBR (1). This heterodimerization leads $G \alpha, \beta$, and $\gamma$ (2) to activate MMP-9 (3). Upon activation, MMP-9 removes EBP (4), which in turn activates Neu-1 (5). Crosstalk between these activated components leads to the phosphorylation and subsequent activation of insulin receptor substrate 1 (IRS1) (6), initiating the phosphoinositide 3-kinase - protein kinase B (PI3K-AKT) pathway, in addition to others, without the presence of insulin. Taken in part from Haxho et al [8] ( 2017 The Authors (c 2017 Published by Elsevier Inc. https: / / doi.org/10.1016/j.cellsig.2017.12.006. The CC-BY license allows users to copy, to create extracts, abstracts and new works from the Article.

\section{Metabolic Syndrome}

Metabolic syndrome is defined as a combination of cardio-metabolic risk factors that lead to obesity, T2DM, and hypertension, all of which are primarily characterized by unhealthy body measurements [2,9]. The manifestation of MetSyn has been attributed to insulin resistance; as such, for this review, we will focus on insulin signaling and insulin resistance (used interchangeably with low insulin sensitivity) as it pertains to MetSyn [9]. It is thought that the peripheral effects of insulin signaling and the body's resistance to it account for the differential expression of MetSyn observed across individuals and its associated conditions such as polycystic ovary syndrome (PCOS) [13]. Therefore, a thorough understanding of insulin resistance and the IR in pathologies that are directly and indirectly related to MetSyn is essential, particularly when identifying whether GPCR-biased agonism could contribute to the development of insulin resistance through the over-activation of IR signaling.

\section{Metabolic Syndrome and the Relationship between Insulin Receptor (IR) in Mitigating a Pathological Phenotype}

Due to metabolic syndrome being a combination of disorders that involves changes in sensitivity to insulin and by extension, the action of the IR, it is perhaps not surprising that alterations in the activity of the IR have been correlated with several pathologies including hypertension, type 2 diabetes mellitus, and obesity [2,9], in addition to cardiovascular disease and diseases of the gastrointestinal (GI) tract. As such, underlying mechanisms that contribute to these diseases may be related to the 
novel phenomenon of GPCR-biased agonism for IR activation. An additional facet that may contribute to this complexity is the possibility of the gut microbiota composition modulating this link.

\subsection{Cardiovascular Disease: Implications of the Renin-Angiotensin System in IR Signaling}

The renin-angiotensin system (RAS) plays a central role in the physiological and pathological responses of the cardiovascular system. Its primary effector hormone, angiotensin II (ANG II), induces its effects through GPCR signaling pathways as well as IR stimulation [14]. Both signaling pathways have also been shown to converge together in order to mediate their effects [15].

The majority of the physiological effects of ANG II, including vasoconstriction and blood pressure regulation, are mediated by angiotensin type 1 receptors $\left(\mathrm{AT}_{1} \mathrm{Rs}\right) . \mathrm{AT}_{1} \mathrm{Rs}_{\mathrm{s}}$ are part of the GPCR superfamily and are widely distributed in all organs including the liver, adrenal glands, brain, lungs, kidneys, heart, and vasculature [16]. The ANG II GPCR-dependent pathway that contributes to vasoconstriction has been extensively researched and explained in detail elsewhere [17]. In brief, $\mathrm{AT}_{1} \mathrm{Rs}$ form complexes that activate phospholipase C (PLC), which in turn activates inositol-1,4,5-triphosphate $\left(\mathrm{IP}_{3}\right)$ and diacylglycerol (DAG) within seconds. $\mathrm{IP}_{3}$ binds to its receptor on the sarcoplasmic reticulum, allowing for the efflux of calcium into the cytoplasm. Activated myosin light chain kinase (MLCK) phosphorylates the myosin light chain and enhances the interaction between actin and myosin, resulting in smooth muscle cell contraction [18]. DAG then leads to sustained protein kinase C (PKC) activation, which promotes sustained muscle contraction, revealing the underlying role that GPCRs may play in the pathogenesis of hypertension [19].

Some clinical and pharmacological studies have confirmed the link between GPCR signaling and insulin receptor cascade activation by ANG II, in which ANG II infusion is known to induce insulin resistance, and ANG II converting enzyme inhibitors (ACE) inhibitors and $\mathrm{AT}_{1} \mathrm{R}$ blockers improve insulin sensitivity [20]. Moreover, the ANG II receptor antagonist, irbesartan, improved whole-body insulin sensitivity in part due to improved glucose transport in skeletal muscles. Additionally, chronic administration of irbesartan was accompanied by a reduction of fasting plasma glucose [21]. This enhanced hepatic insulin sensitivity and diminished hepatic production in the fasting state may constitute possible explanations for the observed effects of irbesartan.

Insulin resistance is proposed to be a significant driver of cardiovascular disease [22]. Recent reports have demonstrated that ANG II interacting with the IR can lead to insulin resistance, representing an underlying mechanism that could lead to cardiovascular disease. Specifically, ANG II interrupts IRS1 signaling at multiple levels, which may explain the severity of cardiovascular diseases in diabetic patients [14]. The ACE inhibitor, temocapril, significantly reduced plasma glucose and insulin concentration in mice with T2DM by enhancing the action of the bradykinin-nitric oxide (BK-NO) system [23]. This finding may be due to the fact that IR signaling involves the phosphatidylinositol 3-kinase (PI3K) pathway, with IRS1 binding PI3K being necessary to elicit the downstream actions of insulin [24]. For example, AKT is a downstream effector of PI3K and plays a central role in the metabolic action of insulin including glucose transport, synthesis of glycogen, and insulin-induced vasodilation [25]. The complexity of its activation is crucial to understanding the advent of insulin resistance as a result of the RAS. For example, downregulation of AKT by PKC may explain the development of insulin-resistant states. Several studies have shown that $\mathrm{AT}_{1} \mathrm{R}$ stimulation leads to activation of PKC [26], while others have shown that prior activation of PKC- $\alpha$ inhibits the ability of insulin to stimulate the enzymatic activity of AKT [27]. Figure 3 shows a schematic diagram by which these interactions occur. This GPCR-IRS1 crosstalk in the activation of PKC may explain the development of severe cardiovascular pathology in insulin-resistant patients [27].

Additionally, $\mathrm{AT}_{1} \mathrm{R}$-mediated signaling leads to the activation of the extracellular signal-regulated kinase (ERK) and c-Jun N-terminal kinase (JNK) pathways [28]. Andreozzi et al. [29] demonstrated that ANG II impaired insulin signaling via ERK/JNK activation and increased phosphorylation of IRS1, resulting in a downregulation of PI3K-AKT activation, which as mentioned, is a crucial component of insulin signaling [28]. 


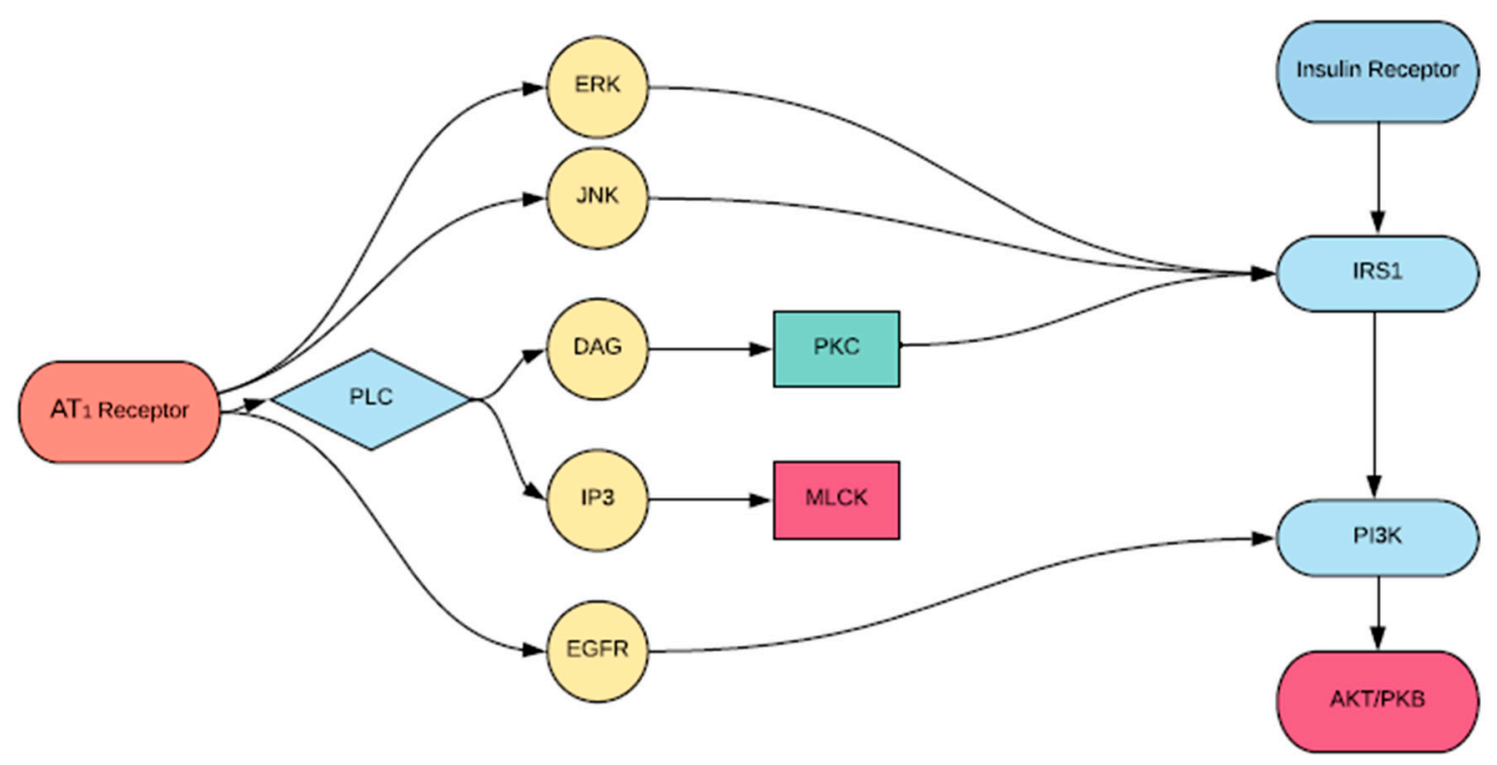

Figure 3. Proposed scheme of angiotensin (ANG) II-induced inhibition of protein kinase B (AKT) activation by insulin. Vascular agonist ANG II activates protein kinase C (PKC), which inhibits phosphorylation of insulin receptor substrate 1 (IRS1), phosphoinositide 3 kinase (PI3K) activation, and AKT activation.

The pathogenesis of chronic vascular diseases such as those implicated in MetSyn is dependent on the complex crosstalk of various cell signaling systems. The RAS and IR signaling pathways are related through shared mediators and effectors, thereby implicating RAS activation in the development of insulin resistance within metabolic syndrome due to ANG II promoting the pathophysiology of atherosclerosis, hypertension, and congestive heart failure in endothelial cells [30]. A more thorough understanding of this connection may aid in the development of more efficacious pharmacological agents for both hypertension and insulin resistance.

\subsection{Bradykinin, Irritable Bowel Syndrome, and Metabolic Syndrome}

Metabolic regulation and inflammation are highly integrated processes contributing to metabolic syndrome, with the prothrombotic and proinflammatory properties of MetSyn having direct implications for conditions such as inflammatory bowel disease (IBD) [31,32]. One of the two major forms of IBD, ulcerative colitis (UC), is a chronic non-specific colitis involving lesions to the mucosa and submucosa [33]. The co-occurrence of MetSyn and IBD in some patients is important to consider, as the presence of both of these conditions translates to a higher risk of developing atheroembolic disease and colorectal cancer [34,35]. Despite the fact that only one study by Yorulmaz et al. reported a higher frequency of MetSyn in patients with UC [36], it is possible that a common molecular mechanism may underpin both of these conditions.

Bradykinin (BK), a key bioactive kinin in the multienzyme cascade in the kallikrein-kinin system (KKS), has been implicated in the pathogenesis and progression of UC via the mediation of vasodilation, inflammation, pain, and edema UC [37-42]. It is believed that BK exerts its effects via high-affinity binding at the constitutively expressed bradykinin 2 receptor $\left(B_{2} R\right)$ throughout the central and peripheral tissues [33]. Moreover, while the ACE is known to play a role in BK inactivation, ACE inhibitors have been shown to enhance the effects of BK at the $B_{2} R$ [43] (Figure 4).

Due to the close relationship between the ACE and KKS systems, ACE inhibitors and $B_{2} R$ agonists such as BK have been suggested to represent new ways of targeting insulin resistance [23,44]. Shiuchi et al. showed that HOE-140, an antagonist at the $B_{2} R$, as well as the nitric oxide (NO) synthase inhibitor, L-NAME, both attenuated the observed enhanced glucose uptake by temocapril, an ACE 
inhibitor [23]. More recently, Talbot and colleagues showed that $B_{1} R$ contributes to insulin resistance and metabolic syndrome while claiming that $\mathrm{B}_{2} \mathrm{R}$ has been associated with a preventive role in insulin resistance [44]. In addition to contributing to T2DM, BK also appears to play a direct role in UC [37-42]. $\mathrm{BK}$ and other selective $\mathrm{B}_{2} \mathrm{R}$ agonists have been shown to induce contraction in both normal healthy and inflamed mouse colon preparations, as well as in induced colitis models with upregulated $B_{2} R$ densities [40]. In a $B_{1} R$ knockout mouse model in which exposure to dextran sulfate sodium (DSS) was used to chemically induce UC, prevention of colitis exacerbation was achieved entirely with a selective $B_{2} R$ antagonist [37]. In several other DSS-induced UC models, treatment with a selective $B_{2} R$ antagonist was reported to reduce experimental colitis significantly [39,42]. Taken together, the fact that BK plays a role in both MetSyn and UC, as well as due to the co-occurrence of these conditions in certain populations, we predict that a potential molecular mechanism directly relating MetSyn and UC may exist involving GPCR-biased agonism for the IR.

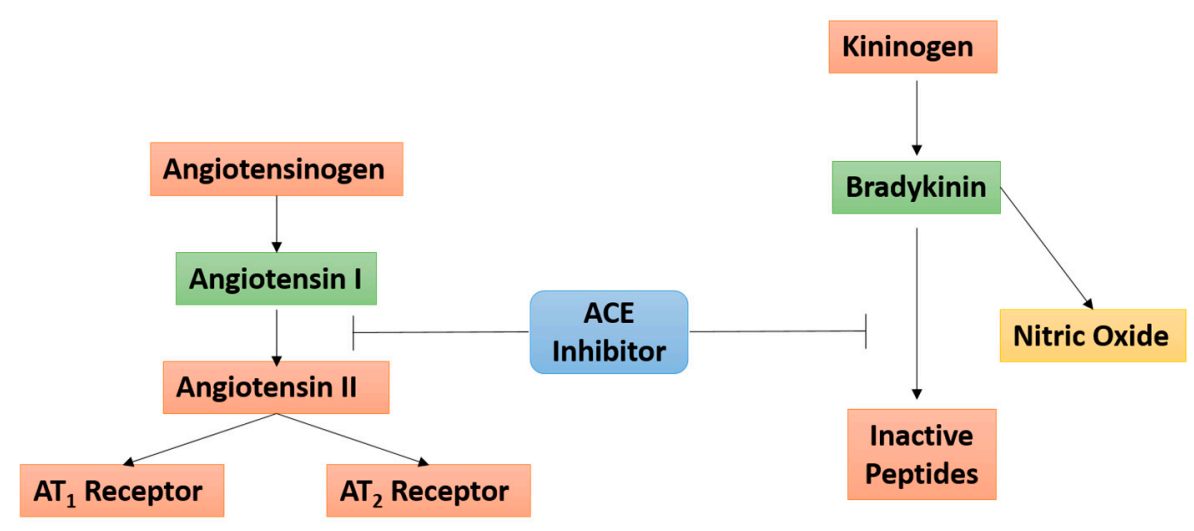

Figure 4. Angiotensin converting enzyme (ACE) inhibitors linking the angiotensin and bradykinin signaling pathways. ACE inhibitors prevent the conversion of angiotensin I to angiotensin II within the renin-angiotensin system, and prevent the conversion of bradykinin to inactive peptides in the kallikrein-kinin system. The $\mathrm{T}$ bars are indicative of the inhibitory action of ACE on activated Angiotensin I (as shown by the green box) and Bradykinin. The red boxes indicated inactive proteins.

Until now, there has been a lack of evidence suggesting a relationship between the insulin receptor, MetSyn, and BK in inducing UC. However, GPCR-biased agonism involving BK, the IR, and the PI3K-AKT signaling pathway may represent the missing link between UC and MetSyn [8]. Haxho et al. recently reported that $B_{2} R$ exists in a multimeric receptor complex with the NMBR, IR $\beta$, and Neu-1 in naïve and stimulated HTC-IR cells [8]. BK signaling at the cell surface initiates a biased GPCR agonist-induced, IR $\beta$ trans-activation-signaling axis mediated by Neu-1 sialidase and glycosylation of the IR [8]. However, the imbalanced cytokine secretion and the ensuing inflammatory responses that accompany them induce mucosal damage, leading to the development of UC. Huang et al. reported that p-AKT expression was significantly increased in the intestinal mucosa of UC patients compared with controls [33]. Additionally, Hayashi et al. reported that deficiency of PI3K resulted in suppression of DSS-induced acute colitis via the production of interleukin-10 (IL-10) in intestinal macrophages [45]. Considering that both BK and the PI3K-AKT signaling pathway contribute to UC, it is possible that NMBR-MMP9-IR $\beta$ crosstalk may be one of the molecular mechanisms relating BK and PI3K-AKT signaling to the induction of UC. The findings of Haxho et al. give rise to the possibility that BK initiates the PI3K-AKT signaling via biased GPCR agonist-induced transactivation of IR $\beta$ [8].

While the application of GPCR agonists such as BK for the treatment of conditions that fall under metabolic syndrome represents immense potential, patients who suffer from both IBD and metabolic syndrome must be taken into special consideration. If GPCR agonists such as BK are deemed as therapeutic targets for MetSyn, those who are at an increased risk of developing IBD or currently living with it as comorbidity will need to be taken into account. The GPCR biased agonist BK may 
exacerbate IBD in patients already living with the condition, as evidenced in various in vivo and in vitro models [37-42], and consequently, alternative approaches to the management of metabolic syndrome may be warranted in this population. The link proposed to exist between BK and PI3K via biased GPCR and IR signaling [8] requires further investigation to determine whether GPCR agonists can be used in the treatment of metabolic syndrome in patients with IBD. Based on available preclinical data, it may be the case that exacerbation of IBD [41] may be an unwanted side-effect of GPCR agonist therapy in this subgroup of patients. While metabolic syndrome is serious comorbidity for patients with IBD that should be managed, the use of GPCR agonists may be ill-advised due to newfound NMBR-MMP9-IR $\beta$ crosstalk that may be contributing to UC.

\subsection{Moderators of the IR-GPCR Signaling Link}

\subsubsection{Gut Microbiota}

The gut microbiota consists of millions of bacteria, viruses, and fungi, and begins taking shape during childbirth [46]. Although the interactions and effects of the gut flora with the human host are not fully understood, it has been implicated in the development of insulin resistance, obesity, and metabolic syndrome, and may be mediated through interactions with the IR or GPCRs [47]. For example, there are distinct differences in the major phyla that comprise the gut microbiota of lean versus obese individuals. Obese individuals have higher concentrations of Firmicutes than Bacteroidetes compared to leaner individuals who have a higher Bacteroidetes and lower Firmicutes concentration [48]. These findings suggest that the phyla of bacteria found in the human gut are correlated with the development of obesity, implicating the gut flora in insulin metabolism. The link between the IR and GPCR may result in changes in gut motility and permeability of individual molecules, which in turn get absorbed into the systemic circulation and lead to the activation of different metabolic and inflammatory processes [49].

Since it is well established that GPCRs closely interact with the insulin receptor, they are thought to affect insulin metabolism, including the amount of energy that is readily available to the host, and are involved in lipid and insulin metabolism. Samuel et al. [50] have shown that mice deficient in certain subtypes of GPCR proteins, particularly Gpr41, are significantly leaner and weigh less than control mice. Gpr41 and Gpr43 are both receptors for short chain fatty acids (SCFAs) and can be found in the colon, adipocytes, and many other tissues. They are activated by SCFAs such as acetate, propionate, and butyrate, with different SCFAs binding with various affinities to each of Gpr41 and Gpr43 [51]. Ligand stimulation of Gpr41 or Gpr43 by SCFAs releases hormones such as leptin that slow down gut motility, allowing more SCFAs to be extracted and stimulate lipogenesis [52]. Gpr43 activation has also been shown to lead to inhibition of the insulin signaling pathway in adipose tissues, which results in suppression of fat accumulation and weight loss in mice [53]. These studies suggest a strong interaction between the gut microbiota, both GPCR proteins, and the insulin receptor.

The development of a low-grade inflammatory state seen in metabolic syndrome represents another mechanism by which the gut microbiome affects insulin metabolism, described as metabolic endotoxemia [54]. Fat-rich diets alter the gut microbiome and favor the colonization of gram-negative bacteria. Lipopolysaccharides (LPS), which are released from the cell walls of dying bacteria are absorbed into the systemic circulation and are thought to contribute to metabolic endotoxemia [55]. Once LPS binds CD14 proteins on the surface of macrophages, multiple inflammatory processes are initiated that ultimately affect insulin sensitivity. Cani et al. reported that mice experiencing inflammation had increased weight, hyperglycemia, and hyperinsulinemia while mice with mutant CD14 proteins did not develop insulin resistance or diabetes [54]. These findings suggest that this inflammatory state caused by certain species of gut bacteria is contributing to obesity and insulin resistance. Also, Brugman et al. [56] have shown that by altering the gut microbiome in mice through the administration of antibiotics, there is a decreased incidence of developing type 1 diabetes and insulin resistance. Therefore, it can be concluded that a strong correlation exists between the gut 
microbiome and the inflammatory state seen in metabolic syndrome and insulin resistance by these interactions. However, additional studies are required to investigate whether there is a correlation between gut bacteria in influencing insulin receptor and GPCR protein activation.

\subsubsection{The role of Ghrelin on IR Signaling in Obesity}

Ghrelin, a peptide hormone found primarily in the gastrointestinal tract, specifically in the oxytonic glands of the gastric fundus and the anterior pituitary gland, has been shown to play a role in metabolic disorders including obesity and T2DM [57,58]. Endogenous ghrelin stimulates the release of growth hormone $(\mathrm{GH})$ and directly modulates feeding habits, glucose homeostasis, and energy balance [58]. Orexigenic neural circuitry maintains this systemic balance by communicating with the GI system and central nervous system (CNS) [59]. In addition to its complex role in providing energy, homeostasis, and GH secretion, alterations in ghrelin are also indicative of meal anticipation [60]. These mechanisms of action are illustrated in Figure 5 and depict the response of various organs of the GI tract to Ghrelin. These alterations are particularly significant because plasma ghrelin levels are inversely correlated with obesity, weight gain, and insulin resistance [61]. By extension, abnormally high levels of plasma ghrelin during states of hunger may be implicated in metabolic diseases and may be regulated through GPCRs and IR cross-talk mechanisms.

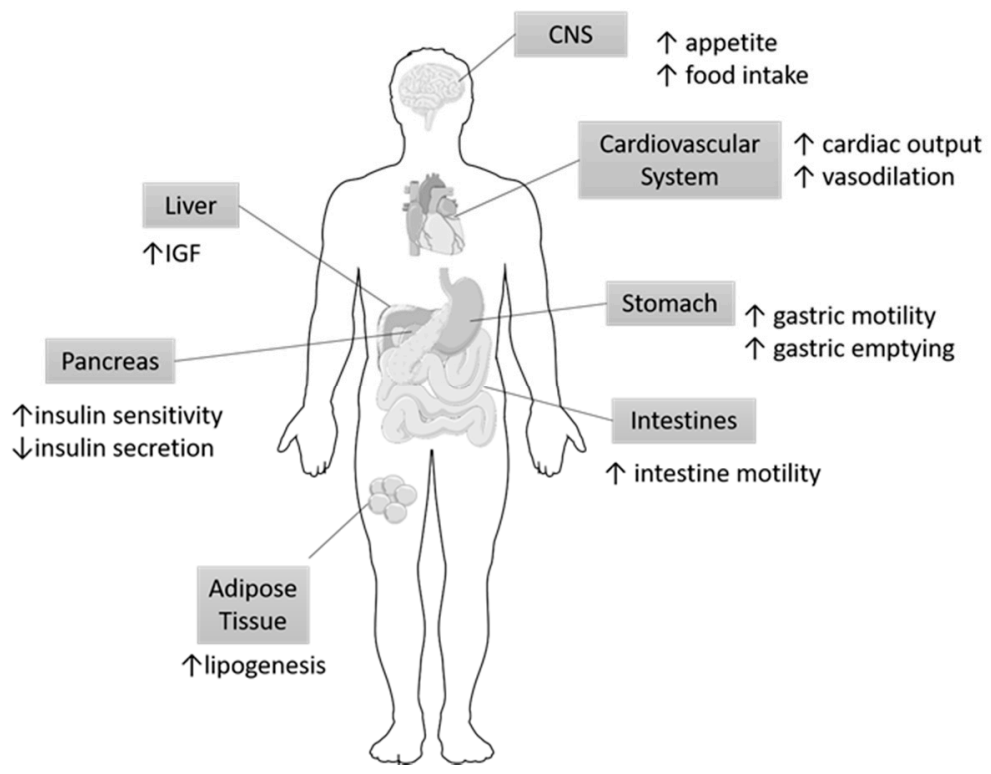

Figure 5. Organ specific targets of Ghrelin. Ghrelin has been shown to exert its action on multiple organs. Most notably, ghrelin modulates eating habits and has been correlated with metabolic syndrome. The arrows indicate the respective increase or decreases in specific functions of the organs participating in metabolism in response to Ghrelin. IGF, Insulin growth factor; CNS, central nervous system.

The proposed link between ghrelin and obesity was evaluated in a study by Tschöp, Smiley, and Heiman [58] that showed that ghrelin administration in mice and rats resulted in weight gain and decreased fat utilization. It was determined that the weight gain not be a direct result of hyperphagia but rather of an inadequate energy metabolism. Ghrelin injections during the resting phase and active feeding phase increased the respiratory quotient $(\mathrm{RQ})$, indicating increased carbohydrate utilization and reduced fat utilization. Moreover, when the mice and rats were administered $\mathrm{GH}$, there was an increase in energy utilization in both light and dark periods, indicating that GH acts independently from ghrelin in energy homeostasis.

Ghrelin exerts its action by binding to the ghrelin receptor (GHSR), which is also known as the growth hormone secretagogue receptor. The GHSR exists in two isoforms: 1a and 1b; however, 
1a will be the primary focus of this paper. GHSR1a is a heterotrimeric GPCR known to stimulate growth hormone secretion when expressed on somatotrophs in the anterior pituitary gland. Ghrelin binding to GHSR1a results in a conformational change of the receptor and subsequent downstream intracellular signaling cascades [62]. Of particular interest is the signal transduction that occurs through calcium ion $\left[\mathrm{Ca}^{2+}\right]$ signaling, as the downstream actions lead to an increase in cytosolic calcium $\left[\mathrm{Ca}^{2+}\right]_{\mathrm{i}}$ concentration in pancreatic $\beta$-islet cells that stimulate insulin release. These findings suggest that ghrelin stimulates insulin release and, furthermore, that $\mathrm{Ca}^{2+}$ may be a messenger signal for ghrelin in pancreatic $\beta$-cells [63]. Thus, ghrelin levels play a critical role in regulating insulin release and resistance.

More specifically, Murata et al. [64] reported that the activation of ghrelin/GHSR1a is involved in the alteration of IRS1 signaling. Physiologically, the IRS1 is activated by PI3K-AKT phosphorylation; however, ghrelin was shown to increase IRS1-associated PI3K-MAPK activity and inhibited AKT activity. This suggests that ghrelin up-regulates both tyrosine phosphorylation and insulin-dependent tyrosine phosphorylation of IRS1. Additionally, ghrelin and insulin showed an additive increase in the tyrosine phosphorylation of IRS1 [64]. This is particularly important as ghrelin and insulin-induced increases of PI3K and MAPK may be linked to an energy-rich state such as obesity, as these pathways regulate cell proliferation.

When ghrelin-induced IRS1 phosphorylation occurs, it does not occur through the IR, but rather through an independent cascade through the GHSR. Ghrelin does not increase the tyrosine phosphorylation of IR $\beta$ chain, as an antagonist for the GHSR resulted in a decrease in ghrelin-induced tyrosine phosphorylation of IRS1 [64]. As shown in Figure 6, it has been speculated that the ghrelin/GHSR downstream signaling cascade, which is a GPCR-pathway, can cross-talk with the insulin-signaling pathway through the IR. Collectively, the ghrelin/GHSR and the PI3K-AKT signaling pathway may suggest a role in the development of obesity. Furthermore, the observations made by Haxho et al. regarding NMBR-MMP9-IR $\beta$ crosstalk [8] may be applied to ghrelin in that it may initiate PI3K-AKT signaling via biased GPCR agonist-induced transactivation of IR $\beta$.

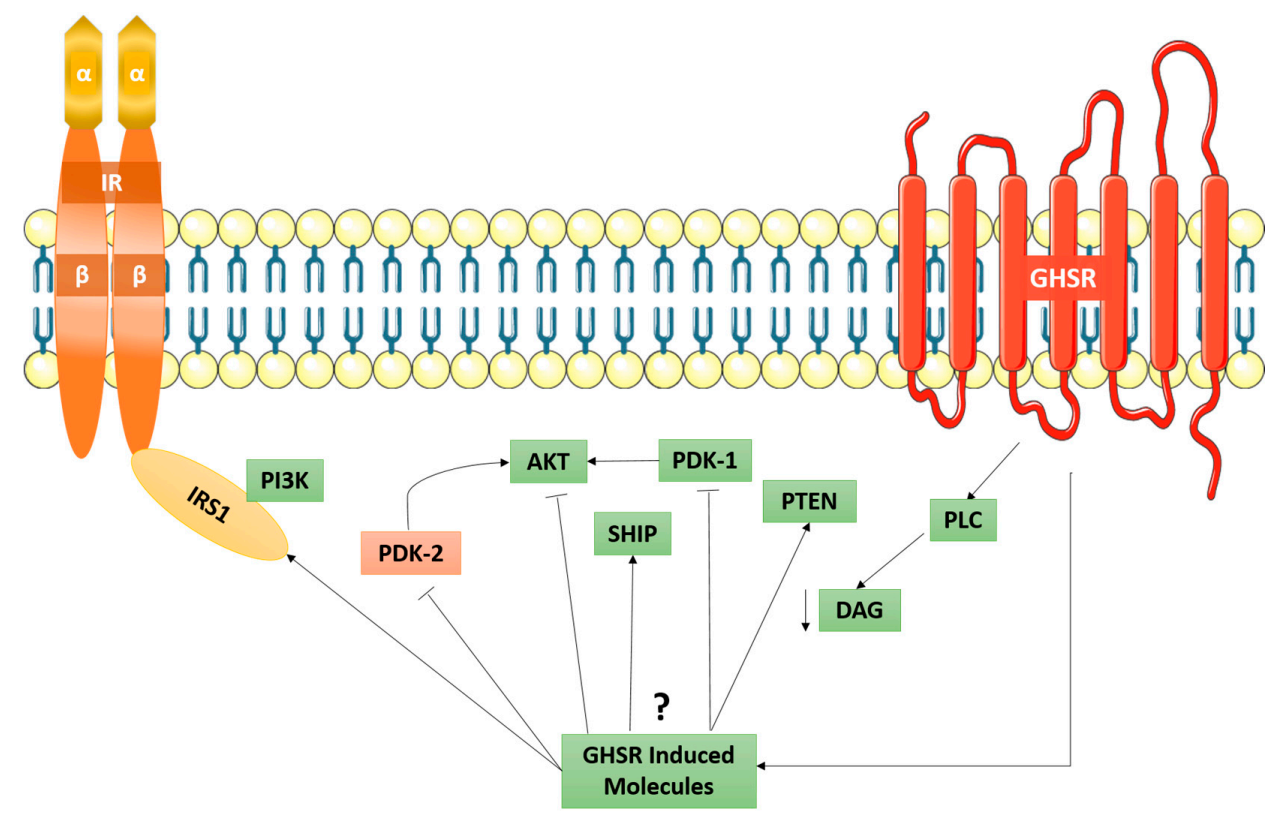

Figure 6. Proposed GHSR induced mechanism of signal transduction in relation to the IR. Here, the possible GHSR-induced molecules are shown to exert their effects by activating or inhibiting several signalling pathways. More importantly, it has been proposed that the inhibiting mechanism of AKT kinase by ghrelin is responsible for the disassociation of the IRS1-PI3K-AKT pathway. Taken in part from Murata et al. [64]. 
In summary, ghrelin results in an overall anabolic state by increasing energy gain and GH secretion. Fasting and high plasma glucose levels increase the level of circulating ghrelin and may suggest an underlying link to metabolic diseases such as obesity. Though ghrelin is primarily released through the gastric fundus, it has been found in the hypothalamus, which suggests its role in energy homeostasis through the central nervous system [58,65]. Although the relationship between ghrelin and metabolic diseases has been investigated, it is possible that the upregulation of the GHSR signaling cascade with the primary agonist being ghrelin may have a cross-talk link between the neuroendocrine axis of GH and insulin signaling and the regulation of energy balance [58].

\section{GPCR-IR Signaling in Pancreatic Cancer}

Neuropeptides and their corresponding GPCRs have been implicated in the autocrine and paracrine stimulation of human cancers including pancreatic ductal adenocarcinoma (PDAC). The interactions with intracellular and transmembrane signal transduction pathways in relation to the insulin receptor, although not entirely understood, have been studied in-depth and shed some light on cancer cell progression, maturation, growth, and treatment [66-68]. Thus, the possibility of a link existing between GPCR-biased agonism and selectively moderating IR activation could have implications for the progression of pancreatic cancer.

In pancreatic cancer PANC-1 cells, crosstalk between GPCRs and IR receptor-signaling pathways has revealed that IR-dependent potentiation of mitogenic agonist, neurotensin, is related to the mammalian target of rapamycin complex 1 (mTORC1) pathway [69]. Following IR activation, the subsequent downstream signaling cascade results in the activation of AKT, which in turn activates mTORC1 [70]. Activation of mTORC1 regulates the PI3K-AKT pathway by negatively inhibiting IRS1 [71]. As previously outlined, this rapamycin-sensitive PI3K-AKT-mTORC1 signaling pathway is a key component of IR signaling in pancreatic cells [13]. The importance of the mTORC1 in regulating the IR has been further substantiated through studies investigating the effects of mTORC1 inhibition, as blocking the mTORC1 pathway causes inhibition of the IRS1 and potentiates the AKT pathway, which is followed by a subsequent increase in insulin sensitivity at the IR [71,72].

Concerning pancreatic cancer, studies have demonstrated that exposure to insulin results in a higher number of pancreatic cancer cells responding to low picomolar concentrations of neurotensin, a GPCR agonist [73]. This is of particular importance, as neurotensin stimulates tumor cell growth in addition to GPCR agonist neuropeptides gastrin-releasing peptide, neuromedin B, gastrin, cholecystokinin, and arginine vasopressin [74]. Interfering with this neuropeptide signaling, as well as intricate connections with other signaling pathways, might offer insight into new therapeutic approaches in the treatment of human cancers.

Therefore, as it relates to PDAC, the rapamycin-sensitive mTORC1 pathway mediates a link between IR and GPCR signaling pathways [75]. Blocking the mTORC1 pathway leads to abolition of the potentiation of GPCR and phosphatidylinositol 4,5-bisphosphate (PIP2)-inositol triphosphate (IP3)-induced calcium release. The release of calcium by IP3 and IP3-receptors in the endoplasmic reticulum is an important regulator of autophagy in cancers [76]. As such, a drug that blocks mTORC1 will have two-fold effect in patients with type 2 diabetes suffering from pancreatic ductal carcinoma $[77,78]$. Therefore, the potential crosstalk between IR and GPCR should be further studied in relation to the association of pancreatic cancer and diabetes because of this common pathway. Although the relationship between diabetes and pancreatic cancer has been investigated, the possibility of crosstalk between the IR and GPCRs will shed light on further pathogenesis and treatment of this deadly disease.

\section{Polycystic Ovarian Syndrome (PCOS)}

Polycystic Ovarian Syndrome (PCOS) is a commonly recognized endocrine and metabolic disease that affects women of reproductive age and can give rise to additional metabolic diseases, including T2DM [79]. While its etiology remains unknown, it is characterized by severe insulin 
resistance, hyperandrogenism, menstrual disorders, and polycystic ovaries that can be seen with ultrasound [80,81]. These abnormal levels of androgen, coupled with high concentrations of circulating insulin, inhibit sex hormone binding protein (SHBP) secretion and result in increased circulating androgen levels and exacerbated clinical symptoms [80].

PCOS is characterized by hyperinsulinemia and hyperandrogenism, the latter of which has been associated with an overexpression of ovarian RAS (OVRAS) [82]. Due to the routinely low estrogen and elevated androgen levels of PCOS follicles, the potential stimulatory action of ANG II on estrogen production has been suggested by several studies [83-85]. As outlined in Section 4.1, ANG II is the predominant player within the RAS system and contributes to insulin resistance. The relationship between ANGII, adipogenesis, and insulin resistance has been comprehensively examined elsewhere [86-88]. In brief, these relationships demonstrated that angiotensinogen and ACE were found in adipocytes in obese humans, thereby raising the possibility that ANG II was produced locally and could exert local effects contributing to insulin resistance [89]. Moreover, culturing of granulosa cells exhibited upregulation of ANG II receptors (angiotensin type 1 receptor, $\mathrm{AT}_{1} \mathrm{R}$, and angiotensin type 2 receptors, $\mathrm{AT}_{2} \mathrm{R}$ ) [86]. Intrinsic generation of angiotensin by ovarian follicles may have regulatory feedback mechanisms in OVRAS components such as angiotensinogen, renin, and ANG II receptors [90].

An additional contributing factor, suggested by Dunaif, is the possibility of a defect in the primary steps of insulin signaling, which could result in insulin resistance in women with PCOS [91]. This report observed that $50 \%$ of PCOS-positive fibroblasts (PCOS-ser) displayed a marked decrease in autophosphorylation of the IR [91]. Subsequent phosphor-amino acid analysis showed decreased insulin-dependent receptor tyrosine phosphorylation and increased insulin-independent receptor serine phosphorylation. The remaining 50\% of fibroblasts in PCOS-positive women (PCOS-nl) presented with no aberrations in phosphorylation of the IR, and the phenotype and degree of insulin resistance were identical to that of PCOS-ser fibroblasts [91]. These findings suggest that a defect downstream of IR binding to its ligand, such as phosphorylation of IRS1 or activation of PI3K, is responsible for insulin resistance in the subset of PCOS-nl women.

Therefore, if a post-binding defect in receptor signaling is due to increased phosphorylation of the IR and IRS1, it may be the case that upregulation of a GPCR-biased agonist is stimulating said phosphorylation. The most likely candidate for the upregulation of a GPCR agonist may be angiotensin [8]. As mentioned previously, ANG II is a potent GPCR agonist that induces phosphorylation of the IR $\beta$ and IRS1, and the increased number of ANG II receptors that exist in granulosa cells of the ovary suggests a critical link that may exist between the IR and GPCRs.

\section{GPCR-IR Signaling Cross-Talk: Potential Implications in Alzheimer's Disease and Neurocognition}

There is a growing body of evidence that metabolic syndrome and insulin resistance can have an effect on the brain and cause neurocognitive impairment and dementia, with the most notable causes being micro- and macrovascular changes throughout the body [92-94]. In healthy individuals, insulin plays a neuroprotective role in the brain and can help prevent apoptosis of neurons, $\beta$ amyloid toxicity, oxidative stress, and ischemia [95]. However, patients with type I or type II diabetes mellitus have been shown to suffer from cognitive regression [96]. These findings suggest that alterations in glucose homeostasis are a hallmark of these diseases and perturbations in insulin signaling may contribute to the neurocognitive deficits seen in these patients (Figure 7).

Insulin receptors are dispersed throughout the brain but are more pronounced in the hippocampus, olfactory bulb, hypothalamus, amygdala, substantia nigra, basal ganglia, and frontal cortex [97]. These receptors have been implicated in cognitive brain functions such as learning and memory within rodent hippocampus and cerebral cortex, respectively $[98,99]$. When insulin function becomes impaired as a result of conditions such as diabetes, insulin resistance may develop. Consequently, the sustained high level of insulin within the periphery decreases the sensitivity of receptors to glucose uptake [100]. 
Peripheral insulin resistance has been shown to contribute to insulin resistance in the brain by reducing available insulin levels and increasing the levels of beta amyloid $(A \beta)$ formation [101]. This effect can lead to neuronal cell death as $A \beta$ deposition can cause dysfunction in lipid metabolism, signaling cascades, autophagy regulation, and neurotransmitter dysfunction [102]. Two sources of insulin are available to the brain: peripheral insulin, which is heavily correlated with T2DM [103], and central insulin. Peripheral insulin must cross the blood-brain barrier (BBB), which contains brain endothelial cells that have insulin receptors, and is in communication with both the extravascular and CNS circulations [104]. Peripheral insulin is taken up by receptor-mediated transport across endothelial cells of the BBB directly, as well as via receptors expressed on the endothelial cells of the BBB via induction of a secondary signaling cascade [105]. Direct entry of insulin via receptor-mediated transport has been shown to interact with insulin receptors expressed in the brain, thereby influencing the brain's physiology [95].

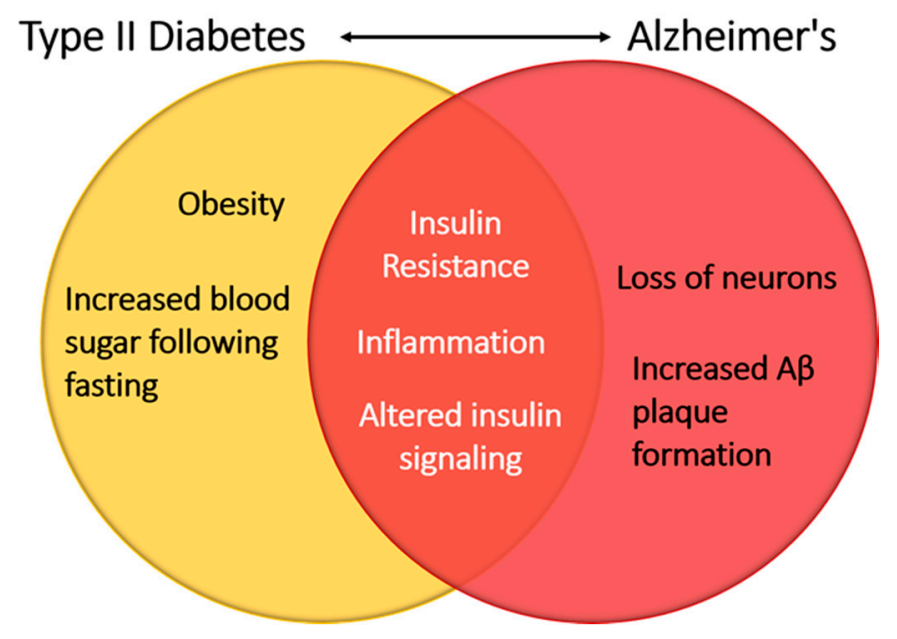

Figure 7. Insulin signaling linking Type II diabetes and Alzheimer's disease. Alterations in glucose homeostasis have led to modification of insulin receptor signaling. Within the central nervous system, insulin receptor signaling perturbations result in the hallmarks of neurodegenerative diseases such as increased $\beta$-amyloid plaque formation and a loss of neurons.

The recent progress in the treatment of diabetes has depended on a continuously evolving understanding of GPCRs and their potential for innovation and drug discovery [106]. The study of GPCRs in the CNS has also led to a deeper appreciation of their role in the development of Alzheimer's disease and involvement in cleavage of the amyloid precursor protein via $\alpha-, \beta-$, and $\gamma$-secretase [107]. Alzheimer's is a neurodegenerative disorder that causes cognitive impairment and memory deficits that lead to dementia due to tau protein hyperphosphorylation and amyloid plaque accumulation [108]. Of particular interest is the 5-hydroxytryptamine $2 \mathrm{C}$ receptor $\left(5-\mathrm{HT}_{2 \mathrm{c}}\right)$ receptor within the choroid plexus, as accumulating evidence suggests that this GPCR may be linked to insulin within the CNS [109]. In rodent models, insulin and IGF-1 signaling were shown to downregulate $5-\mathrm{HT}_{2 \mathrm{c}}$ receptor function in the choroid plexus [109]. Since the 5- $\mathrm{HT}_{2 \mathrm{c}}$ receptor has been proposed to regulate cerebral spinal fluid (CSF) production, and due to insulin having an inhibitory effect on $5-\mathrm{HT}_{2 \mathrm{c}}$ receptor activity, insulin may increase CSF production and change the composition and volume of the CSF [109]. These findings are further confirmed by the co-localization of the 5- $\mathrm{HT}_{2 \mathrm{c}}$ receptor and IRs within different parts of the brain $[110,111]$.

Although more research is required to support the existence of a link between GPCR-biased agonism as it related to the IR, theoretically, targeting a GPCR connected to IRs within the CNS may be a possible avenue to develop a more potent therapy to prevent Alzheimer's disease. Both insulin and the IR have also been suggested to have protective properties against beta-amyloid-induced cell death, with one study citing insulin as an inhibitor of beta-amyloid fibrillation networks [112]. It is, therefore, 
worthwhile to better understand how we can utilize GCPR in relation to the insulin receptor and its relationship with metabolic disease, diabetes, and increased insulin resistance.

\section{Conclusions}

The insulin receptor is expressed in a diverse range of cells throughout the body, and thus aberrations in its activation patterns can directly or indirectly lead to several pathologies. One such disease state is a metabolic syndrome, a collection of pathologies related to metabolism in addition to other conditions such as PCOS, Alzheimer's, and cancer. The activity of the insulin receptor has been shown to be regulated by the GPCRs through the novel phenomenon of GPCR biased agonism. This concept is a particularly vital avenue to continue to explore, as the potential for GPCR biased agonism to affect the insulin receptor may perhaps shed light on the underlying mechanisms involved in contributing to or exacerbating disease conditions related to the insulin receptor.

Acknowledgments: These studies are supported by a grant to Myron R. Szewczuk from Natural Sciences and Engineering Research Council of Canada (NSERC, grant number RGPIN-2015-05301). Bessi Qorri is a recipient of the Queen's Graduate Award (QGA) and the Terry Fox Research Institute Transdisciplinary Training Program in Cancer Research. Manpreet Sambi is a recipient of the QGA. Regina-Veronicka Kalaydina is a recipient of the QGA.

Conflicts of Interest: The authors declare no conflict of interest.

\section{Abbreviations}

$\begin{array}{ll}\text { ACE } & \text { Angiotensin Converting Enzyme } \\ \text { AKT } & \text { Protein kinase B } \\ \text { ANGII } & \text { Angiotensin II } \\ \text { AT }_{1} \text { R } & \text { Angiotensin type 1 receptors } \\ \text { A } \beta & \text { Beta amyloid } \\ \text { B }_{1} \text { R } & \text { Bradykinin Type I Receptor } \\ \text { B }_{2} \text { R } & \text { Bradykinin Type II Receptor } \\ \text { BBB } & \text { Blood Brain barrier } \\ \text { BK } & \text { Bradykinin } \\ \text { CNS } & \text { Central Nervous System } \\ \text { CSF } & \text { Cerebrospinal Fluid } \\ \text { DAG } & \text { Diacylglycerol } \\ \text { DDS } & \text { Dextran sulfate sodium } \\ \text { EBP } & \text { Elastin binding protein } \\ \text { ERK } & \text { Extracellular signal-regulated kinase } \\ \text { GH } & \text { Growth hormone } \\ \text { GHSR } & \text { Ghrelin receptor } \\ \text { GI } & \text { Gastrointestinal } \\ \text { GPCR } & \text { G-protein coupled receptor } \\ \text { IBD } & \text { Irritable Bowel Syndrome } \\ \text { IP } 3 & \text { Inositol-1,4,5-triphosphate } \\ \text { IR } & \text { Insulin receptor } \\ \text { IRS1 } & \text { Insulin receptor substrate 1 } \\ \text { JNK } & \text { c-Jun N-terminal kinase } \\ \text { KKS } & \text { Kallikrein-kinin System } \\ \text { LPS } & \text { Lipopolysaccharides } \\ \text { MetSyn } & \text { Metabolic Syndrome } \\ \text { MLCK } & \text { Myosin light chain kinase } \\ \text { MMP9 } & \text { Matrixmetalloproteinase-9 } \\ \text { mTORC1 } & \text { Mammalian target of rapamycin complex 1 } \\ \text { Neu-1 } & \text { Neuraminidase-1 } \\ & \end{array}$




$\begin{array}{ll}\text { NMBR } & \text { Neuromedin B receptor } \\ \text { NO } & \text { Nitric oxide } \\ \text { OVRAS } & \text { Ovarian Renin Angiotensin System } \\ \text { PCOS } & \text { Polycystic Ovarian Syndrome } \\ \text { PDAC } & \text { Pancreatic ductal adenocarcinoma } \\ \text { PI3K } & \text { Phosphatidylinositol 3-kinase } \\ \text { PIP2-IP3 } & \text { 4,5-bisphosphate-Inositol triphosphate } \\ \text { PKC } & \text { Protein kinase C } \\ \text { PLC } & \text { Phospholipase C } \\ \text { RAS } & \text { Renin Angiotensin System } \\ \text { RQ } & \text { Respiratory quotient } \\ \text { RTK } & \text { Receptor tyrosine kinases } \\ \text { SCFA } & \text { Short chain fatty acids } \\ \text { SHBP } & \text { Sex hormone binding protein } \\ \text { T2DM } & \text { Type two diabetes mellitus } \\ \text { UC } & \text { Ulcerative colitis }\end{array}$

\section{References}

1. Dalle, S.; Imamura, T.; Rose, D.W.; Worrall, D.S.; Ugi, S.; Hupfeld, C.J.; Olefsky, J.M. Insulin induces heterologous desensitization of $\mathrm{g}$ protein-coupled receptor and insulin-like growth factor I signaling by downregulating $\beta$-arrestin-1. Mol. Cell. Biol. 2002, 22, 6272-6285. [CrossRef] [PubMed]

2. Kaur, J. A comprehensive review on metabolic syndrome. Cardiol. Res. Pract. 2014, 2014, 943162. [CrossRef] [PubMed]

3. Haeusler, R.A.; McGraw, T.E.; Accili, D. Biochemical and cellular properties of insulin receptor signalling. Nat. Rev. Mol. Cell Biol. 2017, 19, 31. [CrossRef] [PubMed]

4. De Meyts, P. The insulin receptor: A prototype for dimeric, allosteric membrane receptors? Trends Biochem. Sci. 2008, 33, 376-384. [CrossRef] [PubMed]

5. Dalle, S.; Ricketts, W.; Imamura, T.; Vollenweider, P.; Olefsky, J.M. Insulin and insulin-like growth factor i receptors utilize different $G$ protein signaling components. J. Biol. Chem. 2001, 276, 15688-15695. [CrossRef] [PubMed]

6. Rankovic, Z.; Brust, T.F.; Bohn, L.M. Biased agonism: An emerging paradigm in GPCR drug discovery. Bioorg. Med. Chem. Lett. 2016, 26, 241-250. [CrossRef] [PubMed]

7. Hodavance, S.Y.; Gareri, C.; Torok, R.D.; Rockman, H.A. G protein-coupled receptor biased agonism. J. Cardiovasc. Pharmacol. 2016, 67, 193-202. [CrossRef] [PubMed]

8. Haxho, F.; Haq, S.; Szewczuk, M.R. Biased G protein-coupled receptor agonism mediates neu1 sialidase and matrix metalloproteinase- 9 crosstalk to induce transactivation of insulin receptor signaling. Cell. Signal. 2018, 43, 71-84. [CrossRef] [PubMed]

9. Roberts, C.K.; Hevener, A.L.; Barnard, R.J. Metabolic syndrome and insulin resistance: Underlying causes and modification by exercise training. Compr. Physiol. 2013, 3. [CrossRef]

10. Hubbard, S.R. The insulin receptor: Both a prototypical and atypical receptor tyrosine kinase. Perspect. Biol. 2013, 5, a008946. [CrossRef] [PubMed]

11. Alghamdi, F.; Guo, M.; Abdulkhalek, S.; Crawford, N.; Amith, S.R.; Szewczuk, M.R. A novel insulin receptor-signaling platform and its link to insulin resistance and type 2 diabetes. Cell. Signal. 2014, 26, 1355-1368. [CrossRef] [PubMed]

12. Rozengurt, E.; Sinnett-Smith, J.; Kisfalvi, K. Crosstalk between insulin/insulin-like growth factor-1 receptors and g protein-coupled receptor signaling systems: A novel target for the antidiabetic drug metformin in pancreatic cancer. Clin. Cancer Res. 2010, 16, 2505-2511. [CrossRef] [PubMed]

13. Lee, L.; Sanders, R.A. Metabolic syndrome. Pediatr. Rev. 2012, 33, 459-468. [CrossRef] [PubMed]

14. Mehta, P.K.; Griendling, K.K. Angiotensin ii cell signaling: Physiological and pathological effects in the cardiovascular system. Am. J. Physiol.-Cell Physiol. 2007, 292, C82-C97. [CrossRef] [PubMed]

15. Wheeler-Jones, C.P.D. Cell signalling in the cardiovascular system: An overview. Heart 2005, 91, $1366-1374$. [CrossRef] [PubMed] 
16. Gohlke, P.; Ganten, D.; Lang, R.E.; Unger, T. The renin-angiotensin system: Systemic and local function. Zeitschrift für Kardiologie 1988, 77, 1-12. [PubMed]

17. Ushio-Fukai, M.; Alexander, R.W.; Akers, M.; Lyons, P.R.; Lassègue, B.; Griendling, K.K. Angiotensin ii receptor coupling to phospholipase $d$ is mediated by the $\beta \gamma$ subunits of heterotrimeric $G$ proteins in vascular smooth muscle cells. Mol. Pharmacol. 1999, 55, 142-149. [CrossRef] [PubMed]

18. Yan, C.; Kim, D.; Aizawa, T.; Berk, B.C. Functional interplay between angiotensin ii and nitric oxide. Arterioscler. Thromb. Vasc. Biol. 2003, 23, 26-36. [CrossRef] [PubMed]

19. Baines, R.J.; Brown, C.; Ng, L.L.; Boarder, M.R. Angiotensin II-stimulated phospholipase C responses of two vascular smooth muscle-derived cell lines. Hypertension 1996, 28, 772-778. [CrossRef] [PubMed]

20. Nakagawa, H.; Daihara, M.; Tamakawa, H.; Nozue, T.; Kawahara, K. Effects of quinapril and losartan on insulin sensitivity in genetic hypertensive rats with different metabolic abnormalities. J. Cardiovasc. Pharmacol. 1999, 34, 28-33. [CrossRef] [PubMed]

21. Henriksen, E.J.; Jacob, S.; Kinnick, T.R.; Teachey, M.K.; Krekler, M. Selective angiotensin II receptor antagonism reduces insulin resistance in obese zucker rats. Hypertension 2001, 38, 884-890. [CrossRef] [PubMed]

22. Ginsberg, H.N. Insulin resistance and cardiovascular disease. J. Clin. Investig. 2000, 106, 453-458. [CrossRef] [PubMed]

23. Shiuchi, T.; Cui, T.-X.; Wu, L.; Nakagami, H.; Takeda-Matsubara, Y.; Iwai, M.; Horiuchi, M. Ace inhibitor improves insulin resistance in diabetic mouse via bradykinin and no. Hypertension 2002, 40, 329-334. [CrossRef] [PubMed]

24. Virkamäki, A.; Ueki, K.; Kahn, C.R. Protein-protein interaction in insulin signaling and the molecular mechanisms of insulin resistance. J. Clin. Investig. 1999, 103, 931-943. [CrossRef] [PubMed]

25. Lee, J.H.; Ragolia, L. Akt phosphorylation is essential for insulin-induced relaxation of rat vascular smooth muscle cells. Am. J. Physiol.-Cell Physiol. 2006, 291, C1355-C1365. [CrossRef] [PubMed]

26. Tilley, D.G. G protein-dependent and G protein-independent signaling pathways and their impact on cardiac function. Circ. Res. 2011, 109, 217-230. [CrossRef] [PubMed]

27. Motley, E.D.; Eguchi, K.; Gardner, C.; Hicks, A.L.; Reynolds, C.M.; Frank, G.D.; Mifune, M.; Ohba, M.; Eguchi, S. Insulin-induced akt activation is inhibited by angiotensin II in the vasculature through protein kinase c- $\alpha$. Hypertension 2003, 41, 775-780. [CrossRef] [PubMed]

28. Taniyama, Y.; Ushio-Fukai, M.; Hitomi, H.; Rocic, P.; Kingsley, M.J.; Pfahnl, C.; Weber, D.S.; Alexander, R.W.; Griendling, K.K. Role of p38 MAPK and MAPKAPK-2 in angiotensin II-induced AKT activation in vascular smooth muscle cells. Am. J. Physiol.-Cell Physiol. 2004, 287, C494-C499. [CrossRef] [PubMed]

29. Andreozzi, F.; Laratta, E.; Sciacqua, A.; Perticone, F.; Sesti, G. Angiotensin II impairs the insulin signaling pathway promoting production of nitric oxide by inducing phosphorylation of insulin receptor substrate-1 on ser-312 and ser-616 in human umbilical vein endothelial cells. Circ. Res. 2004, 94, 1211-1218. [CrossRef] [PubMed]

30. Egan, B.M.; Greene, E.L.; Goodfriend, T.L. Insulin resistance and cardiovascular disease. Am. J. Hypertens. 2001, 14, 116S-125S. [CrossRef]

31. Hotamisligil, G.S. Inflammation and metabolic disorders. Nature 2006, 444, 860-867. [CrossRef] [PubMed]

32. Grundy, S.M. Metabolic syndrome: Connecting and reconciling cardiovascular and diabetes worlds. J. Am. Coll. Cardiol. 2006, 47, 1093-1100. [CrossRef] [PubMed]

33. Huang, X.L.; Xu, J.; Zhang, X.H.; Qiu, B.Y.; Peng, L.; Zhang, M.; Gan, H.T. PI3K-AKT signaling pathway is involved in the pathogenesis of ulcerative colitis. Inflamm. Res. 2011, 60, 727-734. [CrossRef] [PubMed]

34. Bernstein, C.N.; Wajda, A.; Blanchard, J.F. The incidence of arterial thromboembolic diseases in inflammatory bowel disease: A population-based study. Clin. Gastroenterol. Hepatol. 2008, 6, 41-45. [CrossRef] [PubMed]

35. Martinez, M.E.; Giovannucci, E.; Spiegelman, D.; Hunter, D.J.; Willett, W.C.; Colditz, G.A. Leisure-time physical activity, body size, and colon cancer in women. Nurses' health study research group. J. Natl. Cancer Inst. 1997, 89, 948-955. [CrossRef] [PubMed]

36. Yorulmaz, E.; Adali, G.; Yorulmaz, H.; Ulasoglu, C.; Tasan, G.; Tuncer, I. Metabolic syndrome frequency in inflammatory bowel diseases. Saudi J. Gastroenterol. 2011, 17, 376-382. [CrossRef] [PubMed] 
37. Marcon, R.; Claudino, R.F.; Dutra, R.C.; Bento, A.F.; Schmidt, E.C.; Bouzon, Z.L.; Sordi, R.; Morais, R.L.T.; Pesquero, J.B.; Calixto, J.B. Exacerbation of dss-induced colitis in mice lacking kinin b(1) receptors through compensatory up-regulation of kinin $\mathrm{b}(2)$ receptors: The role of tight junctions and intestinal homeostasis. Br. J. Pharmacol. 2013, 168, 389-402. [CrossRef] [PubMed]

38. Stadnicki, A.; Sartor, R.B.; Janardham, R.; Stadnicka, I.; Adam, A.A.; Blais, C., Jr.; Colman, R.W. Kallikrein-kininogen system activation and bradykinin (b2) receptors in indomethacin induced enterocolitis in genetically susceptible lewis rats. Gut 1998, 43, 365-374. [CrossRef] [PubMed]

39. Arai, Y.; Takanashi, H.; Kitagawa, H.; Wirth, K.J.; Okayasu, I. Effect of icatibant, a bradykinin b2 receptor antagonist, on the development of experimental ulcerative colitis in mice. Dig. Dis. Sci. 1999, 44, 845-851. [CrossRef] [PubMed]

40. Hara, D.B.; Fernandes, E.S.; Campos, M.M.; Calixto, J.B. Pharmacological and biochemical characterization of bradykinin b2 receptors in the mouse colon: Influence of the tnbs-induced colitis. Regul. Pept. 2007, 141, 25-34. [CrossRef] [PubMed]

41. Devani, M.; Vecchi, M.; Ferrero, S.; Avesani, E.C.; Arizzi, C.; Chao, L.; Colman, R.W.; Cugno, M. Kallikrein-kinin system in inflammatory bowel diseases: Intestinal involvement and correlation with the degree of tissue inflammation. Dig. Liver Dis. 2005, 37, 665-673. [CrossRef] [PubMed]

42. Kamat, K.; Hayashi, I.; Mizuguchi, Y.; Arai, K.; Saeki, T.; Ohno, T.; Saigenji, K.; Majima, M. Suppression of dextran sulfate sodium-induced colitis in kininogen-deficient rats and non-peptide b2 receptor antagonist-treated rats. Jpn. J. Pharmacol. 2002, 90, 59-66. [CrossRef] [PubMed]

43. Ignjatovic, T.; Tan, F.; Brovkovych, V.; Skidgel, R.A.; Erdos, E.G. Activation of bradykinin b1 receptor by ace inhibitors. Int. Immunopharmacol. 2002, 2, 1787-1793. [CrossRef]

44. Talbot, S.; Dias, J.P.; El Midaoui, A.; Couture, R. Beneficial effects of kinin b1 receptor antagonism on plasma fatty acid alterations and obesity in zucker diabetic fatty rats. Can. J. Physiol. Pharmacol. 2016, 94, 752-757. [CrossRef] [PubMed]

45. Hayashi, S.; Hamada, T.; Zinsou, D.G.A.; Oshiro, M.; Itoi, K.; Yamamoto, T.; Kadowaki, M. Pi3k p85 $\alpha$ subunit-deficient macrophages protect mice from acute colitis due to the enhancement of il-10 production. Sci. Rep. 2017, 7, 6187. [CrossRef] [PubMed]

46. Bruzzese, E.; Volpicelli, M.; Squaglia, M.; Tartaglione, A.; Guarino, A. Impact of prebiotics on human health. Dig. Liver Dis. 2006, 38, S283-S287. [CrossRef]

47. Kallus, S.J.; Brandt, L.J. The intestinal microbiota and obesity. J. Clin. Gastroenterol. 2012, 46, 16-24. [CrossRef] [PubMed]

48. Ley, R.E.; Turnbaugh, P.J.; Klein, S.; Gordon, J.I. Microbial ecology: Human gut microbes associated with obesity. Nature 2006, 444, 1022-1023. [CrossRef] [PubMed]

49. Musso, G.; Gambino, R.; Cassader, M. Interactions between gut microbiota and host metabolism predisposing to obesity and diabetes. Annu. Rev. Med. 2011, 62, 361-380. [CrossRef] [PubMed]

50. Samuel, B.S.; Shaito, A.; Motoike, T.; Rey, F.E.; Backhed, F.; Manchester, J.K.; Hammer, R.E.; Williams, S.C.; Crowley, J.; Yanagisawa, M. Effects of the gut microbiota on host adiposity are modulated by the short-chain fatty-acid binding G protein-coupled receptor, gpr41. Proc. Natl. Acad. Sci. USA 2008, 105, 16767-16772. [CrossRef] [PubMed]

51. Brown, A.J.; Goldsworthy, S.M.; Barnes, A.A.; Eilert, M.M.; Tcheang, L.; Daniels, D.; Muir, A.I.; Wigglesworth, M.J.; Kinghorn, I.; Fraser, N.J.; et al. The orphan G protein-coupled receptors gpr41 and gpr43 are activated by propionate and other short chain carboxylic acids. J. Biol. Chem. 2003, 278, 11312-11319. [CrossRef] [PubMed]

52. Xiong, Y.; Miyamoto, N.; Shibata, K.; Valasek, M.A.; Motoike, T.; Kedzierski, R.M.; Yanagisawa, M. Short-chain fatty acids stimulate leptin production in adipocytes through the $\mathrm{G}$ protein-coupled receptor gpr41. Proc. Natl. Acad. Sci. USA 2004, 101, 1045-1050. [CrossRef] [PubMed]

53. Kimura, I.; Ozawa, K.; Inoue, D.; Imamura, T.; Kimura, K.; Maeda, T.; Terasawa, K.; Kashihara, D.; Hirano, K.; Tani, T. The gut microbiota suppresses insulin-mediated fat accumulation via the short-chain fatty acid receptor gpr43. Nat. Commun. 2013, 4, 1829. [CrossRef] [PubMed]

54. Cani, P.D.; Amar, J.; Iglesias, M.A.; Poggi, M.; Knauf, C.; Bastelica, D.; Neyrinck, A.M.; Fava, F.; Tuohy, K.M.; Chabo, C. Metabolic endotoxemia initiates obesity and insulin resistance. Diabetes 2007, 56, 1761-1772. [CrossRef] [PubMed] 
55. Neal, M.D.; Leaphart, C.; Levy, R.; Prince, J.; Billiar, T.R.; Watkins, S.; Li, J.; Cetin, S.; Ford, H.; Schreiber, A.; et al. Enterocyte tlr4 mediates phagocytosis and translocation of bacteria across the intestinal barrier. J. Immunol. 2006, 176, 3070-3079. [CrossRef] [PubMed]

56. Brugman, S.; Klatter, F.; Visser, J.; Wildeboer-Veloo, A.; Harmsen, H.; Rozing, J.; Bos, N. Antibiotic treatment partially protects against type 1 diabetes in the bio-breeding diabetes-prone rat. Is the gut flora involved in the development of type 1 diabetes? Diabetologia 2006, 49, 2105-2108. [CrossRef] [PubMed]

57. Gnanapavan, S.; Kola, B.; Bustin, S.A.; Morris, D.G.; McGee, P.; Fairclough, P.; Bhattacharya, S.; Carpenter, R.; Grossman, A.B.; Korbonits, M.R. The tissue distribution of the mrna of ghrelin and subtypes of its receptor, GHSR, in humans. J. Clin. Endocrinol. Metab. 2002, 87, 2988-2991. [CrossRef] [PubMed]

58. Tschöp, M.; Smiley, D.L.; Heiman, M.L. Ghrelin induces adiposity in rodents. Nature 2000, 407, $908-913$. [CrossRef] [PubMed]

59. Nakazato, M.; Murakami, N.; Date, Y.; Kojima, M.; Matsuo, H.; Kangawa, K.; Matsukura, S. A role for ghrelin in the central regulation of feeding. Nature 2001, 409, 194-198. [CrossRef] [PubMed]

60. Cummings, D.E.; Frayo, R.S.; Marmonier, C.; Aubert, R.; Chapelot, D. Plasma ghrelin levels and hunger scores in humans initiating meals voluntarily without time- and food-related cues. Am. J. Physiol.-Endocrinol. Metab. 2004, 287, E297-E304. [CrossRef] [PubMed]

61. Tschop, M.; Weyer, C.; Tataranni, P.A.; Devanarayan, V.; Ravussin, E.; Heiman, M.L. Circulating ghrelin levels are decreased in human obesity. Diabetes 2001, 50, 707-709. [CrossRef] [PubMed]

62. Yin, Y.; Li, Y.; Zhang, W. The growth hormone secretagogue receptor: Its intracellular signaling and regulation. Int. J. Mol. Sci. 2014, 15, 4837-4855. [CrossRef] [PubMed]

63. Date, Y.; Nakazato, M.; Hashiguchi, S.; Dezaki, K.; Mondal, M.S.; Hosoda, H.; Kojima, M.; Kangawa, K.; Arima, T.; Matsuo, H.; et al. Ghrelin is present in pancreatic $\alpha$-cells of humans and rats and stimulates insulin secretion. Diabetes 2002, 51, 124-129. [CrossRef] [PubMed]

64. Murata, M.; Okimura, Y.; Iida, K.; Matsumoto, M.; Sowa, H.; Kaji, H.; Kojima, M.; Kangawa, K.; Chihara, K. Ghrelin modulates the downstream molecules of insulin signaling in hepatoma cells. J. Biol. Chem. 2002, 277, 5667-5674. [CrossRef] [PubMed]

65. Kojima, M.; Hosoda, H.; Date, Y.; Nakazato, M.; Matsuo, H.; Kangawa, K. Ghrelin is a growth-hormone-releasing acylated peptide from stomach. Nature 1999, 402, 656-660. [CrossRef] [PubMed]

66. Malaguarnera, R.; Belfiore, A. The insulin receptor: A new target for cancer therapy. Front. Endocrinol. 2011, 2, 93. [CrossRef] [PubMed]

67. Schou, K.B.; Pedersen, L.B.; Christensen, S.T. Ins and outs of gpcr signaling in primary cilia. EMBO Rep. 2015, 16, 1099-1113. [CrossRef] [PubMed]

68. Liu, Y.; An, S.; Ward, R.; Yang, Y.; Guo, X.-X.; Li, W.; Xu, T.-R. G protein-coupled receptors as promising cancer targets. Cancer Lett. 2016, 376, 226-239. [CrossRef] [PubMed]

69. Kisfalvi, K.; Rey, O.; Young, S.H.; Sinnett-Smith, J.; Rozengurt, E. Insulin potentiates Ca ${ }^{2+}$ signaling and phosphatidylinositol 4,5-bisphosphate hydrolysis induced by gq protein-coupled receptor agonists through an mtor-dependent pathway. Endocrinology 2007, 148, 3246-3257. [CrossRef] [PubMed]

70. Hahn-Windgassen, A.; Nogueira, V.; Chen, C.-C.; Skeen, J.E.; Sonenberg, N.; Hay, N. Akt activates the mammalian target of rapamycin by regulating cellular ATP level and AMPK activity. J. Biol. Chem. 2005, 280, 32081-32089. [CrossRef] [PubMed]

71. Oliveira, J.C.; Souza, K.K.; Dias, M.M.; Faria, M.C.; Ropelle, E.R.; Flores, M.B.; Ueno, M.; Velloso, L.A.; Saad, S.T.; Saad, M.J. Antineoplastic effect of rapamycin is potentiated by inhibition of IRS-1 signaling in prostate cancer cells xenografts. J. Cancer Res. Clin. Oncol. 2008, 134, 833-839. [CrossRef] [PubMed]

72. Yoon, M.-S.; Choi, C.S. The role of amino acid-induced mammalian target of rapamycin complex 1 (mTORC1) signaling in insulin resistance. Exp. Mol. Med. 2016, 48, e201. [CrossRef] [PubMed]

73. Young, S.H.; Rozengurt, E. Crosstalk between insulin receptor and g protein-coupled receptor signaling systems leads to $\mathrm{Ca}(2+)$ oscillations in pancreatic cancer panc-1 cells. Biochem. Biophys. Res. Commun. 2010, 401, 154-158. [CrossRef] [PubMed]

74. Heasley, L.E. Autocrine and paracrine signaling through neuropeptide receptors in human cancer. Oncogene 2001, 20, 1563-1569. [CrossRef] [PubMed]

75. Bruns, C.J.; Koehl, G.E.; Guba, M.; Yezhelyev, M.; Steinbauer, M.; Seeliger, H.; Schwend, A.; Hoehn, A.; Jauch, K.-W.; Geissler, E.K. Rapamycin-induced endothelial cell death and tumor vessel thrombosis potentiate cytotoxic therapy against pancreatic cancer. Clin. Cancer Res. 2004, 10, 2109-2119. [CrossRef] [PubMed] 
76. Kania, E.; Roest, G.; Vervliet, T.; Parys, J.B.; Bultynck, G. Ip(3) receptor-mediated calcium signaling and its role in autophagy in cancer. Front. Oncol. 2017, 7, 140. [CrossRef] [PubMed]

77. Reifsnyder, P.C.; Flurkey, K.; Te, A.; Harrison, D.E. Rapamycin treatment benefits glucose metabolism in mouse models of type 2 diabetes. Aging 2016, 8, 3120-3130. [CrossRef] [PubMed]

78. Kisfalvi, K.; Eibl, G.; Sinnett-Smith, J.; Rozengurt, E. Metformin disrupts crosstalk between G protein-coupled receptor and insulin receptor signaling systems and inhibits pancreatic cancer growth. Cancer Res. 2009, 69, 6539-6545. [CrossRef] [PubMed]

79. Diamanti-Kandarakis, E.; Dunaif, A. Insulin resistance and the polycystic ovary syndrome revisted: An update on mechanisms and implications. Endocr. Rev. 2012, 33, 981-1030. [CrossRef] [PubMed]

80. Polak, K.; Czyzyk, A.; Simoncini, T.; Meczekalski, B. New markers of insulin resistance in polycystic ovary syndrome. J. Endocrinol. Investig. 2017, 40,1-8. [CrossRef] [PubMed]

81. Turnbaugh, P.J.; Ley, R.E.; Mahowald, M.A.; Magrini, V.; Mardis, E.R.; Gordon, J.I. An obesity-associated gut microbiome with increased capacity for energy harvest. Nature 2006, 444, 1027-1131. [CrossRef] [PubMed]

82. Palumbo, A.; Ávila, J.; Naftolin, F. The ovarian renin-angiotensin system (OVRAS): A major factor in ovarian function and disease. Reprod. Sci. 2016, 23, 1644-1655. [CrossRef] [PubMed]

83. Palumbo, A.; Pourmotabbed, G.; Carcangiu, M.L.; Andrade-Gordon, P.; Roa, L.; DeCherney, A.; Naftolin, F. Immunohistochemical localization of renin and angiotensin in the ovary: Comparison between normal woman and patients with histologically proven polycystic ovarian disease. Fertil. Steril. 1993, 60, 280-284. [CrossRef]

84. Pucell, A.G.; Bumpus, F.M.; Husain, A. Rat ovarian angiotensin ii receptors: Characterization and coupling to estrogen secretion. J. Biol. Chem. 1987, 262, 7076-7080. [PubMed]

85. Kitzman, P.H.; Hutz, R.J. In vitro effects of angiotensin ii on steroid production by hamster follicles and on ultrastructure of the theca interna. Cell Tissue Res. 1992, 268, 191-196. [CrossRef] [PubMed]

86. Underwood, P.C.; Adler, G.K. The renin angiotensin aldosterone system and insulin resistance in humans. Curr. Hypertens. Rep. 2013, 15, 59-70. [CrossRef] [PubMed]

87. Marcus, Y.; Shefer, G.; Stern, N. Adipose tissue renin-angiotensin-aldosterone system (RAAS) and progression of insuline resistance. Mol. Cell. Endocrinol. 2012. [CrossRef]

88. Goossens, G. The renin-angiotensin system in the pathophysiology of type 2 diabetes. Obes. Facts 2012, 5, 611-624. [CrossRef] [PubMed]

89. Karlsson, C.; Lindell, K.; Ottosson, M.; Sjoöstroöm, L.; Carlsson, B.; Carlsson, L.M. Human adipose tissue expresses angiotensinogen and enzymes required for its conversion to angiotensin ii. J. Clin. Endocrinol. Metab. 1998, 83, 3925-3929. [CrossRef] [PubMed]

90. Naftolin, F.; Palumbo, A.; Pepperell, J.R. Potential role of the renin-angiotensin system in polycystic ovaries. Polycystic Ovary Syndr. 1996, 71-88. [CrossRef]

91. Dunaif, A. Insulin resistance and the polycystic ovary syndrome: Mechanism and implications for pathogenesis. Endocr. Rev. 1997, 18, 774-800.

92. Stoeckel, L.E.; Arvanitakis, Z.; Gandy, S.; Small, D.; Kahn, C.R.; Pascual-Leone, A.; Pawlyk, A.; Sherwin, R.; Smith, P. Complex mechanisms linking neurocognitive dysfunction to insulin resistance and other metabolic dysfunction. F1000Research 2016, 5, 353. [CrossRef] [PubMed]

93. Gorelick, P.B.; Scuteri, A.; Black, S.E.; DeCarli, C.; Greenberg, S.M.; Iadecola, C.; Launer, L.J.; Laurent, S.; Lopez, O.L.; Nyenhuis, D. Vascular contributions to cognitive impairment and dementia. Stroke 2011, 42, 2672-2713. [CrossRef] [PubMed]

94. Snyder, H.M.; Corriveau, R.A.; Craft, S.; Faber, J.E.; Greenberg, S.M.; Knopman, D.; Lamb, B.T.; Montine, T.J.; Nedergaard, M.; Schaffer, C.B. Vascular contributions to cognitive impairment and dementia including alzheimer's disease. Alzheimer's Dement. 2015, 11, 710-717. [CrossRef] [PubMed]

95. Blázquez, E.; Velázquez, E.; Hurtado-Carneiro, V.; Ruiz-Albusac, J.M. Insulin in the brain: Its pathophysiological implications for states related with central insulin resistance, type 2 diabetes and Alzheimer's disease. Front. Endocrinol. 2014, 5, 161. [CrossRef] [PubMed]

96. Kodl, C.T.; Seaquist, E.R. Cognitive dysfunction and diabetes mellitus. Endocr. Rev. 2008, 29, 494-511. [CrossRef] [PubMed]

97. Craft, S.; Watson, G.S. Insulin and neurodegenerative disease: Shared and specific mechanisms. Lancet Neurol. 2004, 3, 169-178. [CrossRef] 
98. Zhao, W.-Q.; Chen, H.; Quon, M.J.; Alkon, D.L. Insulin and the insulin receptor in experimental models of learning and memory. Eur. J. Pharmacol. 2004, 490, 71-81. [CrossRef] [PubMed]

99. Zhao, W.; Chen, H.; Xu, H.; Moore, E.; Meiri, N.; Quon, M.J.; Alkon, D.L. Brain insulin receptors and spatial memory correlated changes in gene expression, tyrosine phosphorylation, and signaling molecules in the hippocampus of water maze trained rats. J. Biol. Chem. 1999, 274, 34893-34902. [CrossRef] [PubMed]

100. Craft, S. Insulin resistance syndrome and Alzheimer's disease: Age-and obesity-related effects on memory, amyloid, and inflammation. Neurobiol. Aging 2005, 26, 65-69. [CrossRef] [PubMed]

101. Baker, L.D.; Cross, D.J.; Minoshima, S.; Belongia, D.; Watson, G.S.; Craft, S. Insulin resistance and alzheimer-like reductions in regional cerebral glucose metabolism for cognitively normal adults with prediabetes or early type 2 diabetes. Arch. Neurol. 2011, 68, 51-57. [CrossRef] [PubMed]

102. Rajasekhar, K.; Chakrabarti, M.; Govindaraju, T. Function and toxicity of amyloid beta and recent therapeutic interventions targeting amyloid beta in alzheimer's disease. Chem. Commun. 2015, 51, 13434-13450. [CrossRef] [PubMed]

103. Kahn, S.E.; Cooper, M.E.; Del Prato, S. Pathophysiology and treatment of type 2 diabetes: Perspectives on the past, present, and future. Lancet 2014, 383, 1068-1083. [CrossRef]

104. Banks, W.A.; Owen, J.B.; Erickson, M.A. Insulin in the brain: There and back again. Pharmacol. Therap. 2012, 136, 82-93. [CrossRef] [PubMed]

105. Miller, D.W.; Keller, B.T.; Borchardt, R.T. Identification and distribution of insulin receptors on cultured bovine brain microvessel endothelial cells: Possible function in insulin processing in the blood-brain barrier. J. Cell. Physiol. 1994, 161, 333-341. [CrossRef] [PubMed]

106. Layden, B.; Durai, V.; Lowe, W., Jr. G-protein-coupled receptors, pancreatic islets, and diabetes. Nat. Educ. 2010, 3, 13.

107. Thathiah, A.; de Strooper, B. The role of g protein-coupled receptors in the pathology of Alzheimer's disease. Nat. Rev. Neurosci. 2011, 12, 73-87. [CrossRef] [PubMed]

108. Citron, M. Alzheimer's disease: Treatments in discovery and development. Nat. Neurosci. 2002, 5, $1055-1057$. [CrossRef] [PubMed]

109. Hurley, J.H.; Zhang, S.; Bye, L.S.; Marshall, M.S.; DePaoli-Roach, A.A.; Guan, K.; Fox, A.P.; Yu, L. Insulin signaling inhibits the 5-ht $2 \mathrm{c}$ receptor in choroid plexus via map kinase. BMC Neurosci. 2003, 4, 10. [CrossRef] [PubMed]

110. Pazos, A.; Palacios, J. Quantitative autoradiographic mapping of serotonin receptors in the rat brain. I. Serotonin-1 receptors. Brain Res. 1985, 346, 205-230. [CrossRef]

111. Davidson, D.; Bohannon, N.; Corp, E.; Lattemann, D.; Woods, S.; Porte, D., Jr.; Dorsa, D.; Baskin, D. Evidence for separate receptors for insulin and insulin-like growth factor-i in choroid plexus of rat brain by quantitative autoradiography. J. Histochem. Cytochem. 1990, 38, 1289-1294. [CrossRef] [PubMed]

112. Rensink, A.A.; Otte-Höller, I.; de Boer, R.; Bosch, R.R.; Hans, J.; de Waal, R.M.; Verbeek, M.M.; Kremer, B. Insulin inhibits amyloid $\beta$-induced cell death in cultured human brain pericytes. Neurobiol. Aging 2004, 25, 93-103. [CrossRef]

(C) 2018 by the authors. Licensee MDPI, Basel, Switzerland. This article is an open access article distributed under the terms and conditions of the Creative Commons Attribution (CC BY) license (http://creativecommons.org/licenses/by/4.0/). 